\title{
PRIMARY FIBROSARCOMA OF THE THYROID GLAND: CASE REPORT
}

\author{
Nina Dabelić, Neven Mateša, Tomislav Jukić, Željko Soldić, Davor Kust, Angela Prgomet, Ante Bolanča \\ and Zvonko Kusić
}

Clinical Department of Oncology and Nuclear Medicine, Sestre milosrdnice University Hospital Center, Zagreb, Croatia

\begin{abstract}
SUMMARY - Due to progressive dyspnea, a male patient aged 59 underwent medical examination in 2003 in a local hospital. Neck ultrasound and fine-needle aspiration biopsy (FNAB) of a suspect lesion in the thyroid gland revealed the presence of a malignant neoplasm, i.e. mesenchymal tumor. Immunocytochemistry for epithelial membrane antigen, chromogranin A and leukocyte common antigen (CD45) was negative, while vimentin and S-100 were positive. The patient was referred to a university hospital center, where further oncologic work-up was done. Neck ultrasound revealed a tumor in the left lobe of the thyroid, with extension to the aortic arch. After repeated FNAB, cytologic diagnosis of primary thyroid fibrosarcoma was established. Due to the locally advanced and consequently inoperable disease, primary radiotherapy to the neck region (64 Gy in 32 fractions) was applied, followed by 6 cycles of chemotherapy with doxorubicin. After completion of therapy, computed tomography scan demonstrated significant regression of primary disease, but it was still not amenable to surgical treatment. Thus, the decision of the oncology board was active surveillance of the patient. During 9-year follow up, no signs of progression or activity of the disease were found.
\end{abstract}

Key words: Fibrosarcoma - radiotherapy; Fibrosarcoma - drug therapy; Thyroid neoplasms - radiotherapy; Thyroid neoplasms - drug therapy

\section{Introduction}

Fibrosarcoma is a malignant tumor of mesenchymal cell origin derived from fibrous connective tissue, composed of malignant fibroblasts in a collagen background. It is a rare tumor, accounting for $1 \%-3 \%$ of all human sarcomas. Nowadays, it is diagnosed less frequently, since it can be more reliably distinguished histopathologically from similar lesions, such as desmoid tumors and malignant fibrous histiocytoma. Primary fibrosarcoma of thyroid gland is exceptionally rare ${ }^{1}$, and only few case reports of this type of tumor

Correspondence to: Davor Kust, $M D$, Clinical Department of Oncology and Nuclear Medicine, Sestre milosrdnice University Hospital Center, Vinogradska c. 29, HR-10000 Zagreb, Croatia E-mail: davor.kust@gmail.com

Received June 9, 2015, accepted November 16, 2015 have been reported in the world ${ }^{2-8}$. Until now, there are no known etiologic factors associated with the disease. Most commonly, deep soft tissue of lower extremities (especially thighs and knees) is affected, but it can also develop in upper extremities, chest, head, neck, as well as in other parts of the body (breast, lung and central nervous system). Soft tissue fibrosarcoma usually affects patients of a wider age spectrum than fibrosarcoma of the bone does, and can occur at any age, with the peak incidence between age 30 and 55 . Although it can develop in the areas of previously damaged skin (burns, trauma, chemicals, radiotherapy, etc.), it usually arises from unchanged normal tissue (de novo). The tumor may present different degrees of differentiation: low grade (differentiated), intermediate malignancy and high malignancy (anaplastic). It is generally a large, painless mass deep to fascia and 
has an ill-defined margin. Outcome of patients with soft tissue fibrosarcoma depends on many interrelated factors, among them the size and location of the tumor, histologic grade, and stage of the disease ${ }^{9}$.

\section{Case Report}

A 59-year-old male patient was hospitalized due to progressive dyspnea in a local hospital in March 2003, where thyroid ultrasound (US) and subsequent fine-needle aspiration biopsy (FNAB) showed the existence of a malignant neoplasm, i.e. mesenchymal tumor. Immunocytochemistry for epithelial membrane antigen, chromogranin A and leukocyte common antigen (CD45) was negative, while vimentin and S-100 were positive.

In July 2003, the patient was referred to a university hospital center. Physical examination revealed a large palpable mass in the left lobe of the thyroid. To evaluate the stage of the disease, neck ultrasound (US) and chest and neck computed tomography (CT) were done. A locally advanced process was found in the left lobe of the thyroid, extending up to the aortic arch, $3.5 \mathrm{~cm}$ above the tracheal bifurcation. The described tumor measured $82 \mathrm{~mm}$ in cranio-caudal and $76 \mathrm{~mm}$ in latero-lateral diameter (Fig. 1). The patient underwent US-guided FNAB. Cytologic smears

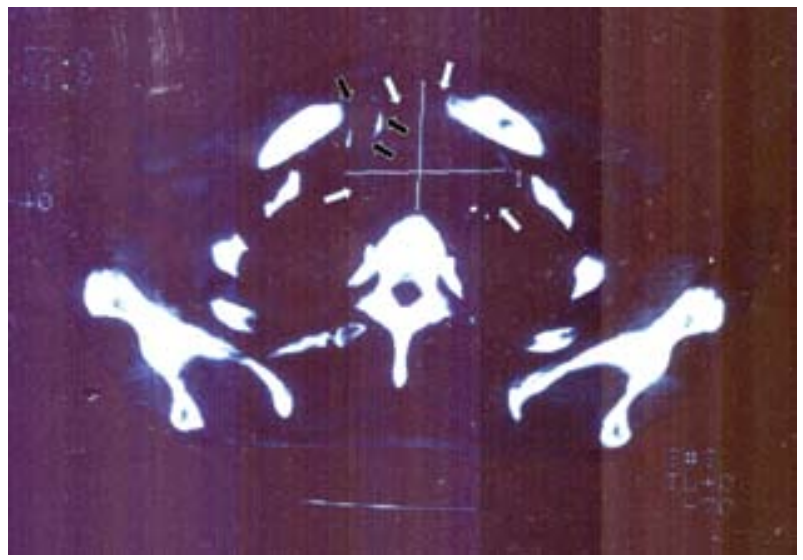

Fig. 1. Chest and neck CT scan before treatment, July 2003: locally advanced process in the left lobe of the thyroid, extending up to the aortic arch, $82 \mathrm{~mm}$ in cranio-caudal and $76 \mathrm{~mm}$ in latero-lateral diameter (white arrows). Trachea was shifted to the right, with narrowed lumen in laterolateral direction (black arrows). were air dried and May-Grünwald-Giemsa stained. The smears were normocellular and consisted of loose bundles of spindle-shaped cells with fusiform nuclei and elongated, poorly delimited cytoplasm (Fig. 2). On the basis of morphological and previously known immunocytochemistry features, FNAB diagnosis of fibrosarcoma was confirmed. Based on the opinions of an otorhinolaryngologist and a thoracic surgeon, the disease was inoperable, and the conclusion of the oncology board was to treat the patient with sequential radiochemotherapy. Total tumor dose of $64 \mathrm{~Gy}$ in 32 fractions was applied, with a short break due to the development of grade 3 radiodermatitis. After radiotherapy, 6 cycles of chemotherapy with doxorubicin were applied (after the first cycle, the dose was
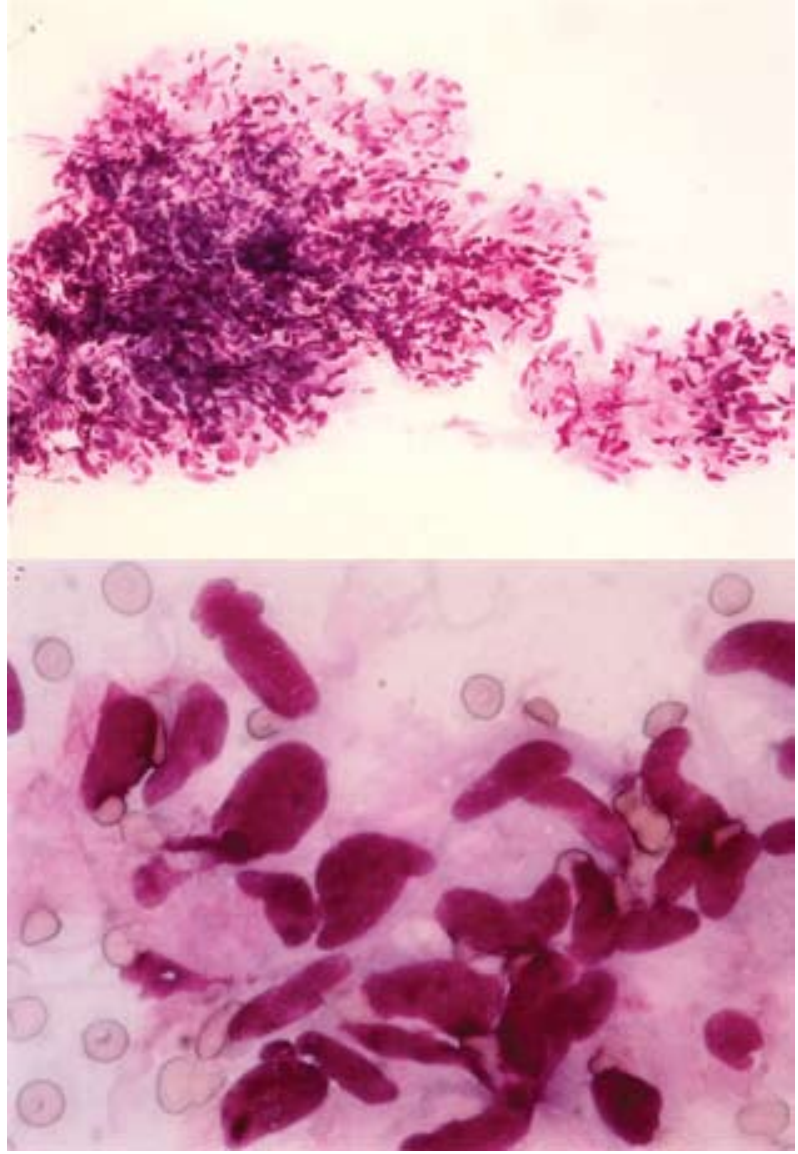

Fig. 2. Cytologic smear of primary fibrosarcoma of the thyroid: the smears were normocellular and consisted of loose bundles of spindle-shaped cells with fusiform nuclei and elongated, poorly delimited cytoplasm. (May-GrünwaldGiemsa $\times M P$, and $\times H P$, respectively) 
reduced by $30 \%$ due to the development of febrile neutropenia). Chemotherapy was completed in February 2004.

After completion of chemotherapy, significant regression of the expansive lesion in the left lobe of the thyroid was recorded (the tumor measured $4.2 \mathrm{~cm}$ on CT scan), with no evidence of enlarged lymph nodes in the mediastinum (Fig. 3). However, it was still not amenable to surgical treatment due to the proximity of vital structures. Follow up head and neck CT in October 2005 demonstrated an inhomogeneous infiltrative process located in the left paratracheal and retrotracheal space. The tumor spread from the lower half of the left lobe of the thyroid, with cranio-caudal diameter of about $6 \mathrm{~cm}$, antero-posterior $3-3.5 \mathrm{~cm}$ and latero-lateral up to $4 \mathrm{~cm}$. Part of the esophagus was surrounded by the tumor, and the trachea was shifted to the right, with narrowed lumen in latero-lateral direction. Last CT scan in September 2009 demonstrated no signs of disease progression. The process was still located in the base of the neck and trachea, with the largest diameter of $5.5 \mathrm{~cm}$, reaching out to the edges of the vertebrae.

The patient underwent regular follow ups, the last one in October 2014, and until now no signs of progression or dissemination of the disease were recorded, so there was no indication for further oncologic treatment. The patient felt subjectively well through-

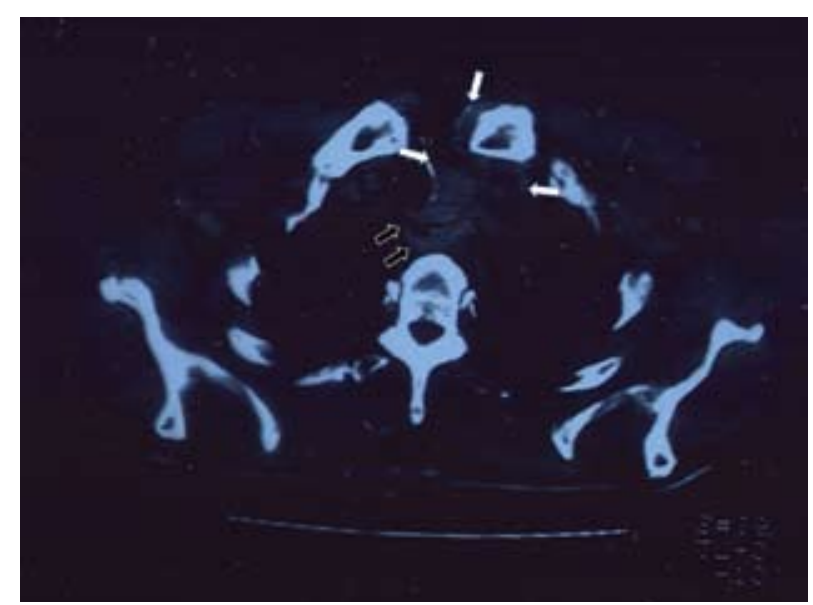

Fig. 3. Chest and neck CT scan after radiotherapy and chemotherapy, March 2004: significant regression of the tumor, $4.2 \mathrm{~cm}$ in diameter (white arrows). Part of the esophagus is surrounded by the tumor (black arrows), and the trachea was still shifted to the right. out the follow up period and reported no symptoms other than mild swallowing difficulties.

\section{Discussion}

Besides fibrosarcoma, all other types of sarcoma can be found in the thyroid gland, including liposarcoma, leiomyosarcoma, chondrosarcoma, osteosarcoma and malignant schwannoma ${ }^{1}$. They all are extremely rare and are only sporadically reported ${ }^{10,11}$. Because of its extremely rare incidence, fibrosarcoma has not yet been included in the TNM classification of thyroid tumors.

Since radiological signs are not specific, the only way to diagnose primary thyroid fibrosarcoma is with the help of a cytologist or pathologist. It has to be noted that cytologic finding may sometimes be inconclusive, and can fail to make the correct diagnosis. In that case, histopathologic diagnosis by taking the sample of the tumor tissue is mandatory. Our patient underwent FNAB twice, first at a local hospital, where the cytologist reported mesenchymal tumor, but no further analysis could be done to determine the tumor subtype. Some recent studies have shown that repeat thyroid FNAB is useful in most cases of primary indeterminate FNAB finding $\mathrm{s}^{12}$. Thus, FNAB was later repeated during work-up in our department, when upon morphological and previously known immunocytochemistry characteristics, the diagnosis of fibrosarcoma was made. Since the result was clear, histopathologic confirmation of the diagnosis was not required.

The natural course of the disease is not characteristic either, with some authors reporting slow-growing tumors, and other rapid course of the disease ${ }^{4}$. The patient underwent primary radiotherapy and chemotherapy, since the locally advanced disease was found during work-up. After primary therapy, the tumor was still not amenable to surgical resection and the patient was followed-up regularly every 6 months. No signs of progression of the disease or of distant metastasis have been found to date, so it is evident that our patient is fortunately in the group of slow-growing thyroid fibrosarcoma. Considering the fact that the tumor was inoperable initially, and even after radio- and chemotherapy, and later on no progression of the disease was found, it is clear that thyroid fibrosarcomas are a very unpredictable group of tumors, and it is still (due to 
a small number of reported cases) not possible to describe precisely their behavior and prognosis. Despite the fact that in our patient, no activity of the disease was found in the last 9 years, the decision of our oncology board was to continue regular follow up.

Thyroid function was assessed at every patient visit; tests included thyroid-stimulating hormone, thyroxine/free thyroxine and triiodothyronine/free triiodothyronine. Despite the large tumor mass that caused atrophic changes by tissue pressure, the patient has remained euthyroid to date.

Standard guidelines for the treatment of thyroid fibrosarcoma are, considering the small number of reported cases, not available. General agreement is that surgical treatment with adequate margins is the mainstay of treatment. The role of radiotherapy and chemotherapy is not clear. Radiotherapy is usually applied postoperatively in case of inadequate surgical resection, while chemotherapy is an option in highgrade tumors (as adjuvant therapy), as well as for inoperable (as it was in our case) or metastatic disease.

\section{References}

1. Scopa CD. Histopathology of thyroid tumors. An overview. Hormones. 2004;3(2):100-10.

2. Agarwal PK, Wahal KM, Mehrota RM. Fibrosarcoma of the thyroid. Indian J Cancer. 1976;13(4):375-8.
3. Botman T. Fibrosarcoma of the thyroid gland. Ned Tijdschr Geneeskd. 1958;102(1):47-9.

4. Titi S, Sycz K, Uminski M. Primary fibrosarcoma of the thyroid gland - a case report. Pol J Pathol. 2007;58(1):59-62.

5. Fries JG, Chamberlin LA, Vandivier TG. Primary fibrosarcoma of the thyroid. Case report. Tex State J Med. 1961;57:981-2.

6. Rilke F, Tommasini DA. Fibrosarcoma of the thyroid gland. Report of two cases. Folia Endocrinol Mens Incretologia Incretoterapia. 1958;11:527-42.

7. Janczak D, Chabowski M, Pawelczyk J, Jelen M, Szydelko T. A giant primary thyroid fibrosarcoma in an octogenarian. Chirurgie (Bucur). 2013;108(4)568-70.

8. Sichel JY, Wygoda M, Dano I, Osin P, Elidan J. Fibrosarcoma of the thyroid in a man exposed to fallout from the Chernobyl accident. Ann Otol Rhinol Laryngol. 1996;105(10):832-4.

9. Nakanishi H, Tomita Y, Ohsawa M, Naka N, Araki N, Ochi $\mathrm{T}$, et al. Tumor size as a prognostic indicator of histologic grade of soft tissue sarcoma. J Surg Oncol. 1997;65(3):183-7.

10. Mitra A, Fisher C, Rhys-Evans P, Harmer C. Liposarcoma of the thyroid. Sarcoma. 2004;8(2-3):91-6. http://dx.doi. org/10.1080/1357-7140400001517

11. Ozaki O, Sugino K, Mimura T, Ito K, Tamai S, Hosoda Y. Primary leiomyosarcoma of the thyroid gland. Jpn J Surg. 1997;27:177-80.

12. Moslavac S, Mateša-Anić $D$, Mateša N, Kusić Z. When to repeat thyroid fine needle aspiration cytology? Acta Clin Croat. 2012;51(4):549-54.

\title{
Sažetak
}

\section{PRIMARNI FIBROSARKOM ŠTITNE ŽLIJEZDE: PRIKAZ SLUČAJA}

\author{
N. Dabelić, N. Mateša, T. Jukić, Ž. Soldić, D. Kust, A. Prgomet, A. Bolanča i Z. Kusić
}

Bolesnik u dobi od 59 godina pregledan je zbog progresivne dispneje u lokalnoj bolnici. Ultrazvukom vrata te citološkom punkcijom suspektne lezije u štitnjači registrirana je maligna neoplazma, tj. mezenhimni tumor. Imunohistokemija je bila negativna na antigen epitelnih membrana, kromogranin A i CD45 te pozitivna na vimentin i S-100. Bolesnik je upućen u klinički bolnički centar, gdje je provedena daljnja onkološka obrada. Ultrazvukom vrata nađen je tumorski proces lijevoga režnja štitnjače sa širenjem na luk aorte. Nakon ponovljene citološke punkcije postavljena je dijagnoza primarnog fibrosarkoma štitnjače. Zbog lokalno uznapredovale i posljedično inoperabilne bolesti provedena je primarna radioterapija regije vrata (64 Gy u 32 frakcije), nakon čega je bolesnik primio 6 ciklusa kemoterapije doksorubicinom. Nakon završetka liječenja kontrolni CT pokazao je značajnu regresiju primarne bolesti koja je, međutim, i dalje bila inoperabilna. S obzirom na navedeno, odluka onkološkog konzilija bila je daljnje aktivno praćenje bolesnika. Tijekom 9 godina praćenja u bolesnika nisu nađeni znakovi progresije niti aktivnosti bolesti.

Ključne riječi: Fibrosarkom - radioterapija; Fibrosarkom - farmakoterapija; Tiroidni tumori-radioterapija; Tiroidni tumori - farmakoterapija 